\title{
Research status and prospect of intelligent fibres and textiles DOI: 10.35530/IT.072.03.1747
}

\section{ABSTRACT - REZUMAT}

\section{Research status and prospect of intelligent fibres and textiles}

Intelligent fibre is a kind of fibre that integrates sensing and information processing. It is similar to biological materials and has intelligent functions such as self-perception, self-adaptation, self-diagnosis, and self-repair. Intelligent textiles refer to textiles that have sensing and responding functions to the environment. Intelligent fibres and their textiles not only have the ability to perceive and respond to external stimuli but also have the ability to adapt to the external environment. In recent years, the research on intelligent fibres has achieved many results in the world, and it is widely used in textiles and clothing industry. Therefore, this paper summarized the research status of intelligent fibre and intelligent textile worldwide, and put forward the research direction in the future. This paper introduced the properties and research status of five kinds of main intelligent fibres, including phase change fibre, shape memory fibre, smart hydrogel fibre, optical fibre and electronic intelligent fibre, and summarized their application in textiles. This paper also introduced the research status of five important intelligent textiles, including intelligent temperature control textile, shape memory textiles, waterproof and moisture permeable textile, intelligent antibacterial textile and electronic intelligent textile. Moreover, it forecasted the development prospects of intelligent fibres and textiles, and pointed out development direction in three aspects of performance optimization, green and safety, industrialization. It provided research reference and guidance for future intelligent fibre and intelligent textile.

Keywords: intelligent fibres, intelligent textiles, phase change fibre, shape memory fibre, smart, hydrogel fibre

\section{Stadiul cercetării și perspectiva fibrelor și textilelor inteligente}

Fibrele inteligente sunt un tip de fibre care integrează detectarea și procesarea informaților. Sunt similare cu materialele biologice și au funcții inteligente, cum ar fi auto-percepția, autoadaptarea, auto-diagnosticarea și auto-repararea. Textile inteligente se referă la materialele textile care au funcții de detectare și răspuns la mediul exterior. Fibrele și materialele textile inteligente nu numai că au capacitatea de a percepe și de a răspunde la stimulii externi, dar au și capacitatea de a se adapta la mediul extern. În ultimii ani, cercetările privind fibrele inteligente au obținut multiple rezultate la nivel mondial și sunt utilizate pe scară largă în industria textilă și a îmbrăcămintei. Prin urmare, această lucrare a rezumat stadiul cercetării fibrelor și materialelor textile inteligente la nivel mondial și a prezentat direcția cercetărilor viitoare. Această lucrare a prezentat proprietățile și stadiul cercetării a cinci tipuri principale de fibre inteligente, incluzând fibra cu schimbare de fază, fibră cu memorie a formei, fibră inteligentă de hidrogel, fibră optică și fibră electronică inteligentă și a prezentat domeniile lor de aplicare. Această lucrare a prezentat, de asemenea, stadiul cercetării a cinci materiale textile inteligente importante, inclusiv materiale textile cu control inteligent al temperaturii, materiale textile cu memoria formei, materiale textile impermeabile și permeabile la umiditate, materiale textile inteligente antibacteriene și materiale textile inteligente electronice. Mai mult, a prognozat perspectivele de dezvoltare a fibrelor și textilelor inteligente și a subliniat direcția de dezvoltare din punctul de vedere al optimizării performanței, ecologiei și siguranței, industrializării. Aceasta a furnizat referințe de cercetare și îndrumări pentru studiul viitoarelor fibre și materiale textile inteligente.

Cuvinte-cheie: fibre inteligente, textile inteligente, fibre cu schimbare de fază, fibre cu memorie a formei, inteligent, fibre hidrogel

\section{INTRODUCTION}

Intelligent fibre refers to the fibre that can sense the change of external environment (machinery, heat, chemistry, light, humidity, electromagnetism, etc.) or internal state and respond to it [1]. And intelligent textile means a new type of textile which simulates the living system and meanwhile [2], has the dual function of both sensation and reaction, and retains the inherent style and technical characteristics of the textile. Intelligent fibre and intelligent textile possess or partly possess the following intelligent functions and life characteristics: sensor function, feedback function, information recognition and accumulation function, respond capability, self-repairing ability self-repair ability and self-adaptation ability [3]. For the last few years, with the development and application of nanotechnology, microcapsule technology, electronic information technology and other cutting-edge technologies, the exploitation of intelligent fibre has been rapidly developed, and a series of emerging intelligent textiles have appeared, thus meeting some specific needs of people. 


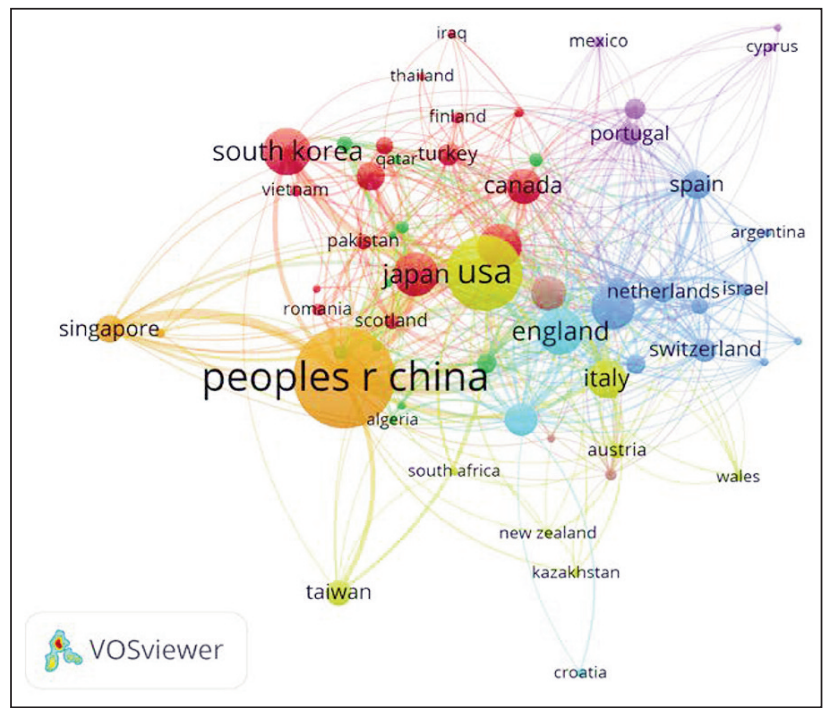

Fig. 1. VOSviewer country/region co-occurrence knowledge map of intelligent fibre group is South Korea (320 papers), England (293 papers), Japan (276 papers), India (259 papers), Germany (248 papers) and Italy (202 papers), the number of their papers is $200-350$ and the strength is equal. Figure 2 shows that the main research power of intelligent textiles comes from about 46 countries and regions in the world. China still has the largest number of papers with 540 papers, followed by the United States (272 papers), and the remaining two countries with more than 100 publications are South Korea (152 papers) and England (130 papers). The distribution of intelligent fibre research organization is shown in figure 3 . There are about 220 research institutions, and there are two institutions with more than 100 papers, namely Chinese Acad Sci (135 papers) and Donghua University (129 papers). Combined with the timeline, it can be seen that Donghua University is also the earliest institution to study intelligent fibres. There are 4 institutions with 50-100 articles, which are Hong Kong Polytech University (89 papers), Harbin Institute of Technology (84 papers), Dalian University of Technology (63 papers) and Nanyang Technology University (57 papers). The distribution of intelligent textile research organization is shown in figure 4. There are about 161 research institutions, only Donghua University with 101 papers and has published more than 100 papers. Chinese Acad Sci (68 articles) ranked second, Hong Kong Polytech University (61 articles) ranked

Fig. 2. VOSviewer country/region co-occurrence knowledge map of intelligent textile

We use VOSviewer visualization tool, and the relevant literature in the web of science core collection database is used as the data source to carry out statistical and visual analysis on all relevant literature in the field of intelligent fibre and intelligent textile. Using "Intelligent fibre" or "Smart Fibre" as intelligent fibre's search terms, and "intelligent textile" or "smart fibre" as intelligent textile's search terms, the retrieval date is October 24, 2020, and the time span is from 1985 to now. A total of 4660 literatures related to intelligent fibre and 1957 literatures related to intelligent textiles were retrieved. Figure 1 shows that the main research power of intelligent fibre comes from about 61 countries and regions in the world, and the distribution of research power is uneven. China is far ahead with 1442 papers, belonging to the first group. Followed by the United States, with 802 papers is the second group. The third

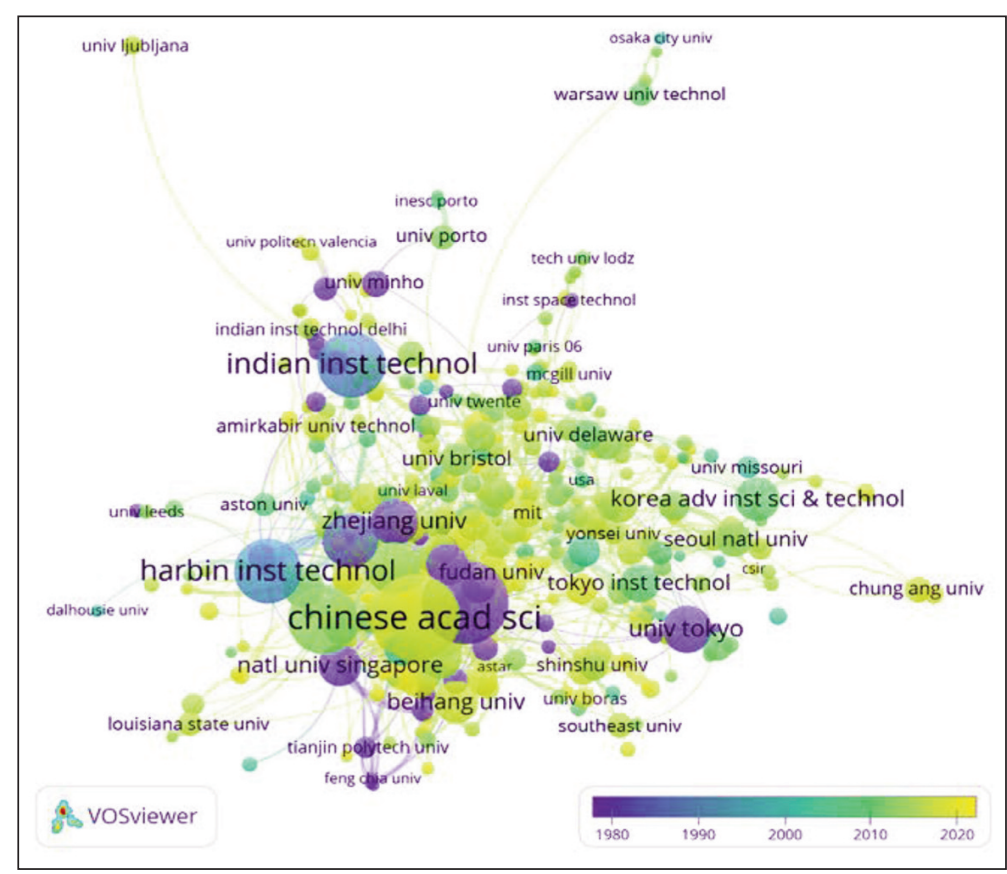

Fig. 3. VOSviewer organization co-occurrence knowledge map of intelligent fibre 


\section{natl res ctr}

lodz univ technol inha univ

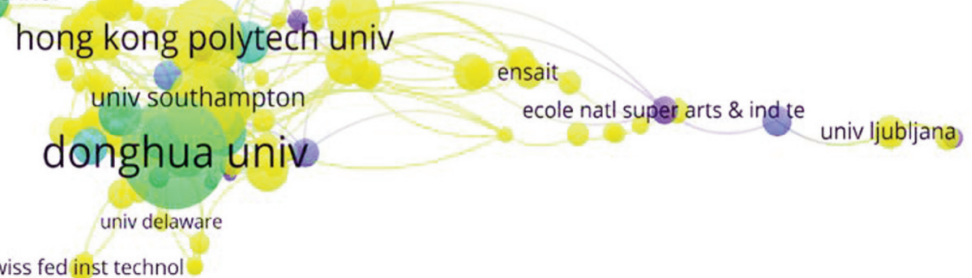

is vosviewer

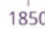

1900

1950

Fig. 4. VOSviewer organization co-occurrence knowledge map of intelligent textile

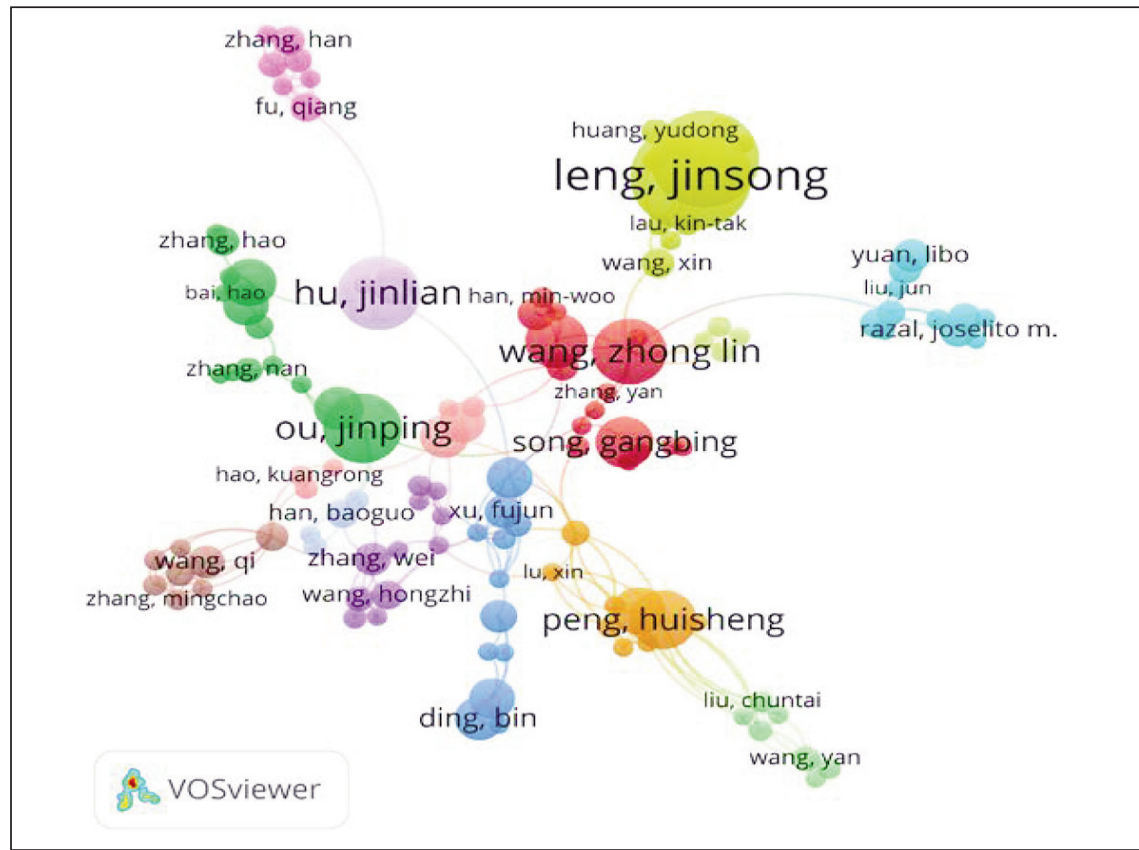

Fig. 5. VOSviewer author co-occurrence knowledge map of intelligent fibre

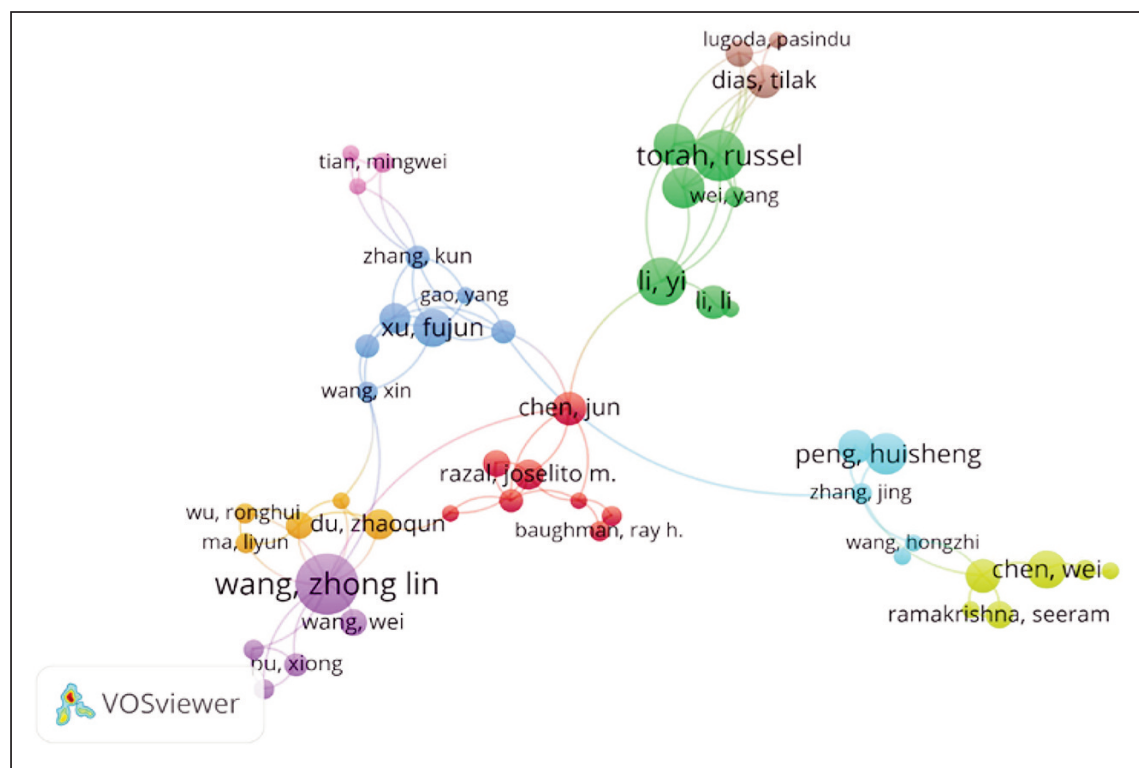

Fig. 6. VOSviewer author co-occurrence knowledge map of intelligent textile third. The number of other articles published was less than 50 . The author distribution of intelligent fibre research is shown in figure 5. There are 1372 authors in total; only 96 authors with more than 5 papers are shown in the figure 5 .

There are 6 authors with more than 10 papers. Among them, Leng Jinsong (29 papers) and Liu Yanju (26 papers) are the most. The rest are Peng Huisheng (16 papers), Ubertini Filippo (15 papers), Sun Xuemei (13 papers) and D'alessandro Antonella (13 papers).

The papers of other authors are in 5 to 10 . The authors' distribution of intelligent textile research is shown in figure 6 . There are 7278 authors in total, only 140 authors with more than 5 papers are shown in the figure 6 . There are 6 authors with more than 10 papers, the most is Koncar Vladan (27 papers), the rest are Wang Zhong Lin (18 papers), Torah Russel (15 papers), Beeby Steve (12 papers), Tudor John (12 papers), Schena Emiliano (10 papers). The rest of other authors' papers are 5 to 10 .

At present, the research on intelligent fibre and intelligent textile is a hot hotspot in the field of textile and garment. Shen Xinyuan et al. [4] made a general statement for intelligent fibres from three aspects of phresponsive gelatinous fibre, photosensitive fibres and temperature-sensitive fibres. Yao Lianzhen et al. [5] expound the preparation, function and application of five typical intelligent fibres, namely shape memory fibre, chameleon fibre, thermalstorage and temperature-regulated fibre, intelligent gelatinous fibre and electronic intelligent fibre, which are of certain reference value for this paper. However, in recent years, some scholars believe that the change in colour of existing chameleon fibres is blind and unavailable to be intelligently adjusted in the light of changing circumstances, so it is of some reasonability to regard them as functional materials. Neunham R.E. divides 
intelligent materials into three categories of negative, positive and high intelligence materials, which have been accepted by many scholars. However, negative intelligent materials are similar to functional materials and do not reach true intelligence, so the intelligent fibres and textiles described in this paper are mainly the latter two categories. He mainly introduces intelligent fibre from five kinds of fibre, such as phase change fibre, shape memory fibre, intelligent gelatinous fibre, optical fibre and electronic intelligent fibre, and sets forth the research status of intelligent textile, and prospects the development trend of intelligent fibre and intelligent textiles.

\section{INTELLIGENT FIBER}

\section{Research status of intelligent fibre}

\section{Phase change fibre}

Phase change fibre is a sort of high-tech fibre product developed by combining phase-change material technology and fibre manufacturing technology [6], which can automatically perceive the variation of environment temperature so as to intelligently regulate the temperature. The phase-change material contained in it can make the fibre have bidirectional temperature regulation and adaptability through solid-liquid or solid-solid reversible conversion: When the ambient temperature is higher than a certain threshold, the material phase transformation absorbs heat to have refrigeration effect. When the ambient temperature is lower than a certain threshold, the material phase transformation releases heat to have heat preservation effect. At present, some representative phase change fibre products in the market include Outlast Comfortemp Thermasorb and Cool Vest [7], which can be used repeatedly in the environment of temperature oscillation, and the frequency of thermal cycles generally reaches more than 1000. Figure 7 shows the preparation method of phase change fibre, the properties of phase change fibres have been greatly optimized by continuous breakthroughs in preparation methods. In recent years, breakthroughs have been made in composite spinning and microencapsulation, for example, Limei

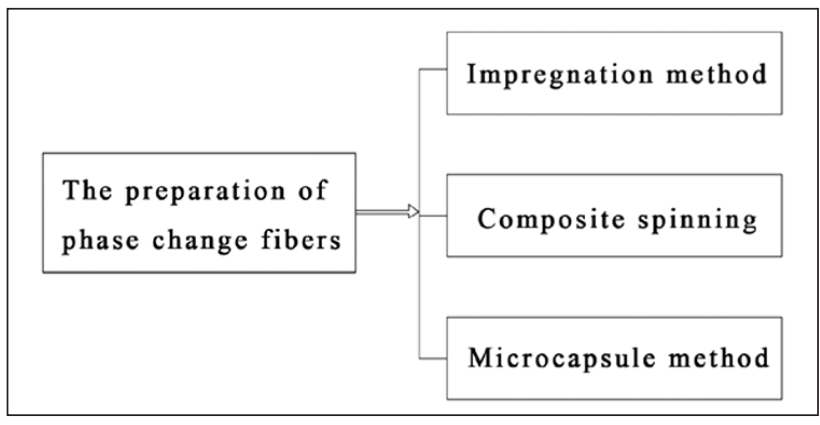

Fig. 7. Preparation method of phase change fibre

Shi et al [8] prepared composite phase change materials by vacuum melting adsorption method, and then obtained composite PET phase change fibres with skin and core. The prepared composite phase change fibres have better temperature regulation performance. The novel sodium alginate/feather keratin-gallyloxy polyethylene glycol (SA/FK-g-APEG) composite phase change fibre was designed and fabricated via centrifugal spinning for the first time by Xueyong Gong et al. [9]. Hongyun Fu [10] prepared soybean wax phase change microcapsules by in-situ polymerization method, and then obtained coaxial composite fibres by electrostatic spinning method, which improved the leakage, chemical instability and poor processing performance of simple phase change materials in practical applications.

\section{Shape memory fibre}

Shape memory fibre refers to a kind of fibre that can recover its initial shape under certain conditions (stress temperature, etc.) after plastic deformation and stimulation in specific conditioned stimulus, whose original shape can be designed as straight line, wave, spiral or other shapes [11], which mainly includes three categories: shape memory alloy fibre, shape memory polymer fibre and shape memory functional fibre processed by finishing agent [12]. At present, the common shape memory alloys are $\mathrm{TiNi}$ system, Cu-base and Fe-base alloys. The preparation process of shape memory fibre is shown in figure 8 , the types of shape memory fibre raw materials

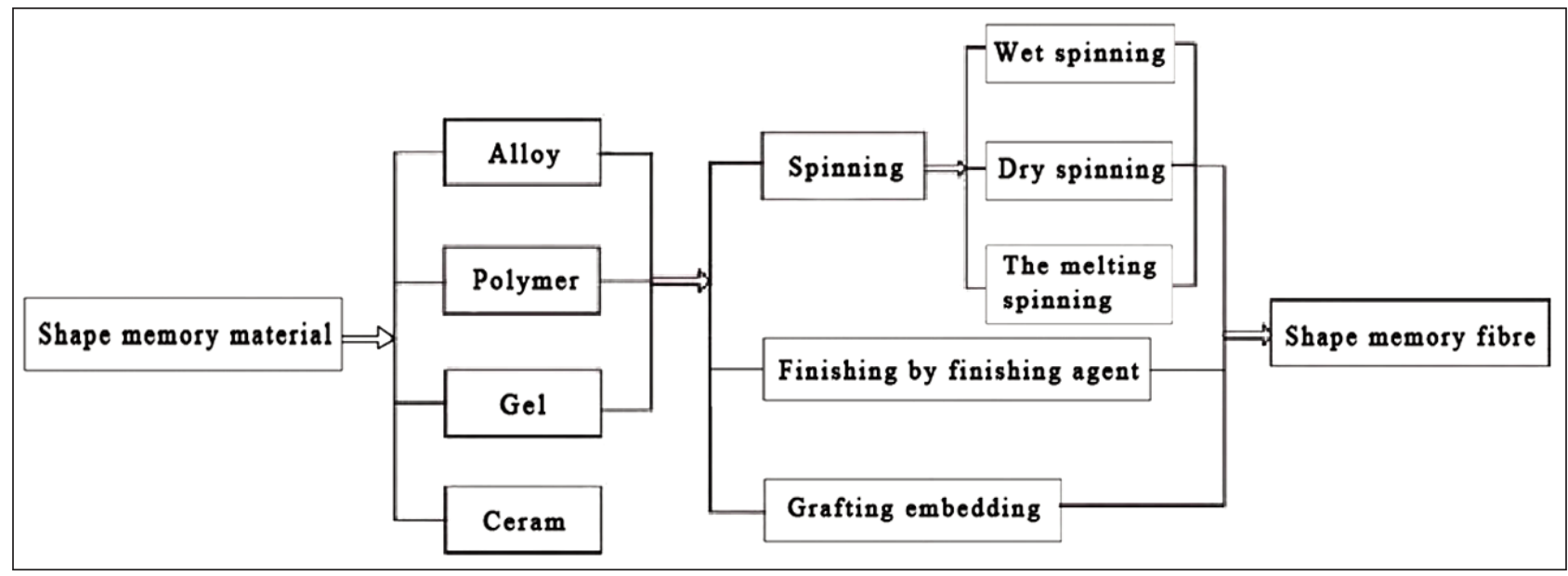

Fig. 7 Preparation process of shape memory fibre 
continue to increase, from the initial shape memory alloy to a variety of shape memory fibres, such as Fangyuan chemical fibre company of China successfully developed the PTT shape memory fibre, and put it into large-scale production, named Fineyarn, which reached the international leading level.

Smart hydrogel fibre

Intelligent gelatinous fibre refers to gelatinous fibre that can change in volume or shape with external stimulation (temperature, $\mathrm{pH}$ value, light, electricity, etc.) According to different stimulus conditions, intelligent gelatinous fibres can be principally divided into $\mathrm{pH}$-responsive gel fibres, temperature-sensitive fibres, photosensitive fibres and electro sensitive fibres, among which $\mathrm{pH}$-responsive gel fibres are the most common. Intelligent gel fibres have adaptability and biocompatibility and are often used in the development and design of intelligent textiles in recent years. Suzhou nanometre of China has made important progress in the field of graphene aerogel smart fibres in 2018, the aerogel team of the Chinese academy of sciences cleverly combined graphene aerogel fibres, phase change materials and super hydrophobic coating to get a flexible and self-cleaning graphene aerogel intelligent phase change fibre, realizing multiple stimulus response functions including energy conversion and storage, self-cleaning, intelligent temperature regulation and heating [13].

Optical fibre

Light-guide fibre is a kind of optical composite fibre that can seal the light energy in the fibre and transmit it in the way of waveguide. It has excellent performance on transmission as well as provides accurate information describing the state of the system at any time, so it is recognized as the preferred sensing material. It has been proverbially used in the production of various types of sensors, in smart clothing, safety clothing and other new garment applications, to realize the understanding of the external environment temperature, pressure, displacement and other conditions as well as the body temperature, heartbeat, blood pressure, and other physiological indicators monitoring. In the past decade, optical fibre has been used in the research of intelligent clothing. For example, Furao Guo developed a human temperature warning system based on optical fibre in smart clothing [14], Guopeng Zhou developed a clothing pressure sensing system based on micro-bending optical fibre [15], Xinyu Tian developed a fibre grating intelligent clothing which can be used for human pulse detection and so on [16].

\section{Electronic intelligent fibre}

Electronic intelligent fibre is a new type of fibre developed based on electronic technology, fusing sensor, communication, artificial intelligence and other hightech means. With people's increasing demand, they have higher requirements on electronic intelligent fibres. At present, the electronic intelligent fibres on the market mainly include antistatic fibres, conductive fibres, etc., among which conductive fibres are the most representative. Conductive fibre refers to a fibre whose specific resistance is lower than $107 \Omega \cdot \mathrm{cm}$ at standard condition (relative humidity 65\%), mainly used for static elimination, electromagnetic wave absorption and electrical signal detection and transmission. After three generations of development, the latest technology is carbon black composite organic conductive fibre [17].

According to the comparative analysis of the five mainstream intelligent fibres mentioned above, the advantages and disadvantages of various intelligent fibres are shown in table 1.

\begin{tabular}{|c|c|c|}
\hline \multicolumn{3}{|c|}{ ADVANTAGES AND DISADVANTAGES OF INTELLIGENT FIBERS } \\
\hline Name & Advantages & Disadvantages \\
\hline Phase change fibre & $\begin{array}{l}\text { With bidirectional temperature regulation } \\
\text { and adaptability, it can be used repeatedly } \\
\text { in the temperature oscillation environment. }\end{array}$ & $\begin{array}{l}\text { It is difficult to control the temperature } \\
\text { of excitation point because of the low energy } \\
\text { of solid-liquid phase change or solid-solid } \\
\text { phase change. }\end{array}$ \\
\hline Shape memory fibre & $\begin{array}{l}\text { It has shape memory effect, high recovery } \\
\text { deformation, good earthquake resistance } \\
\text { and adaptability. }\end{array}$ & $\begin{array}{l}\text { It is hard to handle, and it can't achieve com- } \\
\text { plete lossless bending deformation and recov- } \\
\text { ery under the bending state of some specific } \\
\text { external forces. }\end{array}$ \\
\hline Smart hydrogel fibre & It is adaptive and biocompatible. & $\begin{array}{l}\text { At present, there are differences in mechani- } \\
\text { cal properties between intelligent gel fibres } \\
\text { and organisms. }\end{array}$ \\
\hline Optical fibre & $\begin{array}{l}\text { With excellent transmission performance, } \\
\text { fine diameter, good flexibility and easy pro- } \\
\text { cessing, it is recognized as the preferred } \\
\text { sensor material. }\end{array}$ & There is inherent loss. \\
\hline Electronic intelligent fibre & $\begin{array}{l}\text { It has excellent conductivity and can elimi- } \\
\text { nate static electricity by electron conduc- } \\
\text { tion and corona discharge. }\end{array}$ & $\begin{array}{l}\text { The comfort and softness are poor, and the } \\
\text { safety, durability and power supply continuity } \\
\text { need to be further studied. }\end{array}$ \\
\hline
\end{tabular}




\section{Design thinking of intelligent fibre}

As with other smart materials, bionics is the starting point of intelligent fibre. People can use the principle of bionics, take the cell as the blueprint of intelligent material, and develop the intelligent biological material which is close to the multiple functions of the organism, close to or even more than the organism in function [18].

The main way to develop intelligent fibre is molecular design. According to its stimulus response mechanism, intelligent fibre can be designed to produce only one response to the change of one factor, or to produce only one response to the change of multiple factors, or to produce different responses to the change of different factors [19]. Molecular design here, including polymer structural design and functional group design.

Many substances or materials are inherently intelligent, For example, the properties of some substances or materials (such as colour, shape, size, mechanical properties, etc.) can change with the environment or the conditions of use, also have the ability of self-diagnosis, self-learning and prediction, stimulus response and signal recognition [20]. The optical properties, electrical properties and other physical or chemical properties of some substances or materials can change with different external conditions, so in addition to recognizing and distinguishing signals, self-diagnosis, self-learning and anti-stimulation ability, they can also be developed into substances or materials with dynamic balance and selfmaintenance functions. The structure or composition of some materials can change with the working environment and have the function of self-adaptation and self-adjustment to the environment. Therefore, intelligent fibres can be obtained by combining these existing substances or materials (including blending, addition and hybridization technologies as described later).

\section{Preparative technique of intelligent fibre}

Forming polymer direct spinning

Intelligent fibres can be spun directly by synthesizing intelligent fibre forming polymers through molecular design.

\section{Graft copolymerization}

It is one of the main methods to prepare intelligent fibres to graft some groups with special effects or functions onto the side chains of polymers or one or both ends of polymers.

\section{Crosslinking}

The crosslinking reaction mainly occurs during the polymerization of monomers with a function greater than 2. It can also trigger chains of macromolecules to produce reactive radicals and functional groups, leading to the formation of new chemical bonds between macromolecules. Crosslinking is the main method to prepare adaptive gel fibres.

\section{Blend and add}

By mixing the polymers, inorganic substances or lowmolecular organic compounds with the fibre forming polymers, the traditional single-component processing method can be used to prepare the fibres, which can be endowed with intelligent functions without affecting the original properties of the fibres as much as possible.

\section{Composite spinning and hybridization}

Composite spinning and hybrid composite spinning are two kinds of polymer fluids which are mixed at the inlet of spinneret through their respective flow channels and extruded together. Because the liquid flow quickly solidified, so do not mix, forming a clear interface of the composite fibre.

Polymer chemical reaction

As mentioned above, the existing natural fibres, artificial fibres or synthetic fibres can be endowed with intelligent functions by conducting polymer chemical reactions through molecular design.

\section{Post-processing}

It can also be endowed with intelligent functions by post-processing existing fibres with materials that have intelligent functions of their own.

\section{INTELLIGENT TEXTILES}

Textile fibres are processed and woven into products, which are called textiles. Currently, in the development process of the intelligent textile, the insisting philosophy is that aiming at some particular functional requirements, the corresponding one or several intelligent fibres and other materials are combined, processed or introduced into the textile by means of weaving or finishing, and thus the textiles are developed to meet users' corresponding demand, rather than simply weave one or several types of intelligent fibres into textiles. Therefore, this paper introduces intelligent textile and intelligent fibre separately.

\section{Intelligent temperature control textile}

Intelligent temperature control textile is a kind of textile which can intelligently control fabric temperature to improve its comfort. In accordance with the stimulus-response way to the outer circumstance temperature, it can be split into three categories: thermal insulation textile, cooling textile and temperature-regulating textile. At present, the manufacturing technology of temperature-regulating textile mainly includes coating finishing, composite spinning and microcapsule spinning, and has been developed comparatively mature. In recent years, the research of temperature-regulating textile has made prominent achievements at home and abroad. The United States is the first country to study temperature-regulating textiles. It originally mainly aimed at the Lunar Probe Project, and successfully developed Outlast phase-change material in 1988. After 1994, temperature-regulating textiles were gradually commercialized and their property was constantly improved. Currently, Ureatech "air conditioning" fabric developed by Polytech Company in the United States is relatively advanced, which is a kind of polyurethane coating and temperature-regulating fabric. The research on temperatureregulating textile is relatively late in China. In 2003, 
Baoding Xiongya Textile Group and American Embers International Group successfully developed phase change thermoregulation Loko wool with the "space technology", and produced "warm in winter and cool in summer" clothing for the first time in China. Although many of these products have been industrialized at present, their processing difficulties, poor wearability and durability are still salient.

\section{Shape memory textile}

Shape memory textile usually refers to a kind of textile with superior performances such as shape memory, high recovery deformation, good shock resistance and adaptability, etc., by processing or introducing materials with shape memory function into textiles in the form of weaving or finishing. There are two major processing methods: one is to weave with shape memory fibre the other is to proceed shape memory finishing for textiles. And the methods of shape memory finishing include resin finishing, shape memory polymer finishing, collagen finishing, grafting, embedding and so on. At present, the common finishing means is to press polyurethane film on the upper layer of fabric or apply polyurethane coating. Shape memory textiles can be developed into multitudinous categories, functions of costumes, such as thermal insulation resistance clothing, waterproof and moisture permeable clothing, which are especially used in the parts with high requirements of shape maintenance, back swing of coat, knee of trousers and other parts of clothes to meet the requirements of restoring, and the knitwear and other materials with poor shape preserving to improve fabric performance.

\section{Waterproof and moisture permeable textile}

Waterproof and moisture-permeable textile refers to a kind of functional textile that water cannot infiltrate into the fabric under certain pressure, but the sweat gas emitted by the human body can be diffused or transmitted to the surrounding through the fabric and does not accumulate condensation between the body surface and the fabric, making people subjectively feel no tightness. At present, the processing methods of waterproof and moisture permeable textiles can be summarized into three main methods: ultra-high density structural approach, microporous technology and dense hydrophilic membrane technology. Therefore, waterproof and moisture permeable textiles can be divided into 4 categories: waterproof and moisture permeable high-density textile, micro-porous film waterproof and moisture permeable textile, nonporous film waterproof and moisture permeable textile and intelligent waterproof and moisture permeable textile [21]. But what can be called intelligent textile truly is intelligent waterproof and moisture permeable textile, the typical product is shape memory polyurethane and its waterproof and moisture permeable fabric Diaplex produced by Mitsubishi Heavy Industry in Japan, whose waterproof performance can reach $20,000 \sim 40,000 \mathrm{~mm}$, the water pressure resistance can reach $196.13 \sim 392.26 \mathrm{kPa}$, and the moisture penetration can reach 8,000-12,000 $\mathrm{g} /(\mathrm{m} \cdot 24 \mathrm{~h})$. In addition, its moisture permeability can be adjusted correspondingly with the change of temperature to achieve intelligence. Therefore, it can be suitable for wearing under different conditions, so as to adjust the microclimate inside human clothing, which is mainly used in mountaineering suit, ski suit, sportswear, immersion suit and other clothing now.

\section{Intelligent antibacterial textile}

Waterproof Antibacterial is a process that kills bacteria or inhibits the growth and reproduction of bacteria and their activities by physical or chemical methods. After anti-bacterial treatment, textiles can exert two functions: one is to protect users; the other is to prevent fibre from damage. Antibacterial textiles are mainly acquired by two means: making all kinds of fabrics with antibacterial fibres; the fabric is after treated with antibacterial agents. At present, the latter antibacterial textile is in the majority in the market. Intelligent antibacterial textile is a kind of textile with selective control function to bacteria, which can maintain the growth and reproduction of certain microorganisms on the skin surface at a normal level no matter under mild or intense activity conditions, used in towels, underwear, bed sheets and children's cloth toys, etc. The manufacturing methods of intelligent antibacterial textiles include blending silk method, composite spinning method, grafting modification method, ion-exchange method, wet spinning method and post-finishing method, etc., which are majorly developed on the basis of intelligent gel fibre. For example, gel phase fibre in wet spinning is immersed in the solution of antibacterial agent to seal the solution into the fabric so as to possess antibacterial effect. But the endurance quality of intelligent fight bacterium textile is poor, the mould resistance of the fabric after washing will decline, even disappear, the wash frequency of this kind of product on the market is controlled in 30 times commonly now.

\section{Electronic intelligent textile}

Electronic intelligent textile is a new type of textile developed on account of electronic technology by applying high-tech means such as sensing, communication and artificial intelligence to textile technology. The addition of electronic components provides a new solution for textiles, but meanwhile, it also brings new security loopholes and processing problems, so different from other textiles, the research on electronic intelligent textiles has formed an independent theoretical and practical system. The study on electronic intelligent textiles is relatively late compared with other textiles, but in recent years, it has become a research hotspot in the field of textile and apparel, and is regarded as one of the important trends in the future research. At present, sensing device is a common element in the development of electronic intelligent textiles, whose application makes textiles have the function of perceiving the external environment and the internal state of human body. The clothing safety design centre of Jiangnan University has 


\begin{tabular}{|l|l|l|l|}
\hline \multicolumn{4}{|c|}{ ADVANTAGES AND DISADVANTAGES OF INTELLIGENT TEXTILES } \\
\hline \multicolumn{1}{|c|}{ Name } & \multicolumn{1}{|c|}{ Advantages } & \multicolumn{1}{c|}{ Disadvantages } & \multicolumn{1}{c|}{ Application } \\
\hline $\begin{array}{l}\text { Intelligent temperature } \\
\text { control textile }\end{array}$ & $\begin{array}{l}\text { It can control the temperature } \\
\text { of fabric intelligently. }\end{array}$ & $\begin{array}{l}\text { It is difficult to process, poor } \\
\text { wearability and durability. }\end{array}$ & $\begin{array}{l}\text { For mountaineering clothing, } \\
\text { sking clothing, fire clothing, } \\
\text { etc. }\end{array}$ \\
\hline Shape memory textile & $\begin{array}{l}\text { It has shape memory, high } \\
\text { recovery deformation, good } \\
\text { earthquake resistance and } \\
\text { adaptability. }\end{array}$ & $\begin{array}{l}\text { It can't achieve complete loss- } \\
\text { less bending deformation and } \\
\text { recovery under the bending } \\
\text { state of some specific external } \\
\text { forces. }\end{array}$ & $\begin{array}{l}\text { It can be used in heat insula- } \\
\text { tion clothing, waterproof and } \\
\text { lazy shirt, anti-immersion ther- } \\
\text { mal insulation clothing, etc. }\end{array}$ \\
\hline $\begin{array}{l}\text { Waterproof and moisture } \\
\text { permeable textile }\end{array}$ & $\begin{array}{l}\text { It can intelligently adjust and } \\
\text { control the microclimate in } \\
\text { the clothing, and has the } \\
\text { functions of waterproof and } \\
\text { moisture permeability. }\end{array}$ & $\begin{array}{l}\text { The coating method has rough } \\
\text { handle and poor performance; } \\
\text { the lamination method is diffi- } \\
\text { cult to biodegrade and has } \\
\text { high combustion temperature, } \\
\text { which has a great impact on } \\
\text { the environment. }\end{array}$ & $\begin{array}{l}\text { For mountaineering clothing, } \\
\text { skiing clothing, sports cloth- } \\
\text { ing, life-saving clothing, etc. }\end{array}$ \\
\hline $\begin{array}{l}\text { Intelligent antibacterial } \\
\text { textile }\end{array}$ & $\begin{array}{l}\text { It can protect users and pre- } \\
\text { vent fibre damage. }\end{array}$ & $\begin{array}{l}\text { Generally speaking, the dura- } \\
\text { bility is not good. After wash- } \\
\text { ing, the antibacterial property } \\
\text { of the fabric will decline or } \\
\text { even disappear. At present, } \\
\text { the washing times of such } \\
\text { products on the market are } \\
\text { usually about 30. }\end{array}$ & $\begin{array}{l}\text { For towel, underwear, bed } \\
\text { sheet and children's cloth } \\
\text { toys, etc. }\end{array}$ \\
\hline $\begin{array}{l}\text { It provides a new solution for } \\
\text { textiles and upgrades the } \\
\text { user experience. }\end{array}$ & $\begin{array}{l}\text { It has potential safety hazards } \\
\text { and processing problems, and } \\
\text { its comfort and softness are } \\
\text { limited. }\end{array}$ & $\begin{array}{l}\text { It can be used in medical, } \\
\text { aerospace, national defence } \\
\text { and military fields. }\end{array}$ \\
\hline
\end{tabular}

developed a series of safety clothing with sensing devices, such as traffic safety, medical safety, etc., which is particularly outstanding in the research of safety children's clothing. At the same time, some countries, including the United States, Finland, Japan, Germany, Italy and other countries, the researches in this area have been growing vigorously, and have achieved remarkable results. However, the integration of electronic components and textiles is still the key and difficult points in the development of such textiles.

According to the comparative analysis of the five mainstream intelligent textiles mentioned above, the advantages and disadvantages of all kinds of intelligent textiles are shown in table 2, and their application directions are listed.

\section{PROSPECT}

The study and development of intelligent fibres and intelligent textiles have expedited the upgrading of textiles. In the future, interdisciplinary application will become more and more prevalent in the territory of textile and clothing, thus to improve its core competence. The following tendencies are mainly presented:

\section{Performance optimization}

The prominent feature of intelligent fibre and textile is intelligentization, but because of the limitation of current technical level, the function of a lot of such products is not mature, the phenomenon of simplification is more obvious. In the future, the development and cross-application of multidisciplinary knowledge will promote its development towards the direction of differentiation, compound and systematization, that is, the property is constantly optimized. There are not only products with highlighted functions for specific demands, but also products that meet people's various needs. Simultaneously, the integration means of intelligent materials and textiles are becoming increasingly abundant, which strengthens the systematization of products, among which, intelligent fibres and intelligent textiles that focus on optical properties, thermal properties, electrical properties and electronic information will have broad application prospects, and electronic elements in intelligent fibres and intelligent textiles of electronic information will be more miniaturized and flexible to accommodate the development needs of such products.

\section{Green security}

The launch of a new product must be evaluated to guarantee its safety and reliability. At present, in the development of intelligent fibre and intelligent textile is primarily technology-cantered and pays attention to the realization of functions, but undervalues evaluation. So the security and dependability of the intelligent fibres and intelligent textiles cannot get effective guarantee, which is especially evident in the electronic product. With the constant deepening of the concept of green security, the future development of 
intelligent fibre and intelligent textile will be user-cantered and emphasize the evaluation of products to ensure their green and safety, among which technology is still a crucial part.

\section{Industrialization}

Industrialization can propel the exploitation of a product into a virtuous cycle, so industrialization is the assurance of the progress of intelligent fibre and intelligent textile. If a product wants to achieve the requirement of industrialization, it must satisfy numerous conditions, such as cost, appearance, practicability and so on. Although many of these products have been commercially available at present, most of them are still in the experimental stage, particularly in the electronic intelligent fibre and its textile, there are many difficulties that have not yet been overcome. In the future, the development of intelligent fibre and intelligent textile will be more professional and commercial. On the other hand, the technological multi-function integration will be stressed, especially in the fields of military industry and aerospace; On the other hand, the mass consumers will be taken as the centre, and the products design will be directed at the needs of the target group, so as to meet the needs of the market.

\section{CONCLUSION}

The development and application of intelligent fibre and intelligent textile are the research hotspots in the field of textile and garment nowadays, and also the growing trend in the future. The study and development of such products will benefit the development of military industry, medical care, recreation, entertainment, decoration and other multiple industries, which is concerned with the national economy and people's livelihood. This paper analyses the research status and trend of intelligent fibres and intelligent textiles, and used the VOSviewer visualization tool to perform statistical and visual analysis of all relevant literature in the field of intelligent fibre and intelligent textile in the Web of Science database, and compared the advantages and disadvantages of different types of intelligent fibre and intelligent textile by table, and summarizes the design ideas and preparation technologies of intelligent fibres, hoping to sort out the ideas for future research in this direction and provide a basis for future research.

\section{ACKNOWLEDGEMENTS}

This research was supported by the China Scholarship Council (Project No.201806795029) and Postgraduate Research \& Practice Innovation Program of Jiangsu Province (KYCX19_1849).

\section{REFERENCES}

[1] Shen, L., Hong, W.J., Application research of Intelligent Fiber in Intelligent Safety Clothing Design, In: Cotton Textile Technology, 2018, 42, 78-81

[2] Yin, B., Research status and development trend of intelligent textiles, In: Textile Reports, 2017, 7, 39-42

[3] Zhang, G.L., Du, Y.L., Intelligent Materials and Structural System, In: Peking University Press, Beijing, 2017

[4] Shen, X.Y., Shen, Y., Current Situation and Development Trend of Intelligent Fiber, In: Synthetic Fiber Industry, 2010, 24, 1-5

[5] Yao, L.Z., Yang, W.F., Qiao, Y.L., Research Progress of Intelligent Fiber and Its Textile, In: Dyeing \& Finishing, 2012, $12,43-46$

[6] Li, G.Y., Hong, G., Dong, D.P., Song, W.H., Zhang, X.T., Multiresponsive Graphene-Aerogel-Directed PhaseChange Smart Fibers, In: Advanced Materials, 2018, 30

[7] Gao, C., Kuklane, K. and Holmer, I., Cooling vests with phase change materials - the effect of melting temperature on heat strain alleviation in an extremely hot environment, In: European Journal of Applied Physiology, 2011, 111, $1207-1216$

[8] Shi, L.M., Niu, Y.M., Zhao, Q.H., Wu, X.H., Liu, C.S., Li, Y., Wang, D., Dai, Y.M., Preparation and properties of sheath-core phase-change PET fiber, In: China Synthetic Fiber Industry, 2012, 40, 33-37

[9] Gong, X.Y., Dang, G.Y., Guo, J., Liu, Y.F., Guo, Y.M., Sodium alginate/feather keratin-g-allyloxy polyethylene glycol composite phase change fiber, In: International Journal of Biological Macromolecules, 2019, 131

[10] Fu, H.Y., Preparation and Properties of phase change microcapsules and fibers encapsulated with soy wax, In: Huazhong University of Science and Technology, 2015

[11] Robinson, P., Bismarck, A., Zhang, B.H. Maples, H.A., Deployable, shape memory carbon fibre composites without shape memory constituents, In: Composites Science and Technology, 2017, 145, 96-104

[12] Lendlein, A., Kelch, S., Shape-memory polymers, In: Angewandte Chemie International Edition, 2012, 41, 2034-2057

[13] Xin, X., Suzhou nanometer has made important progress in the field of smart graphene aerogel fibers, In: New Chemical Materials, 2018, 46, 275

[14] Danila, A., Rotaru, V., Muresan, E.I., Istrate, C., Popescu, A., The potential of aroma textiles in North-East Romania, In: Industria Textila, 2019, 70, 487-492, http://doi.org/10.35530/lT.070.05.1621

[15] Zhou, G.P., Design of Clothing Pressure Sensing System Based on Micro-bend Optic-fiber Sensor, In: Knitting Industries, 2015, 12, 74-76

[16] Tian, X.Y., Research on fiber Bragg grating intelligent clothing for human pulse detection, In: Tianjin Polytechnic University, 2015

[17] Chen, N., Functional fiber changes the details of life from the source, In: Textile Science Research, 2019, 3, 48-49 
[18] Shen, X.Y., Design Thinking and Preparing Technolegy of Intelligent Fibers, In: Polymer Bulletin, 2015, 5, 135-141

[19] Shen, L., Zhang, X.Y., A new type of solar charging mountaineering wear, In: Shanghai Textile Science \& Technology, 2016, 44, 16-18

[20] Shel, F., Thermoelastic stability of a composite material, In: Journal of Differential Equations, 2020, 269, 9348-9383

[21] Chirila, L., Cinteza, L.O., Tanase, M., Radulescu, D.E., Radulescu, D.M., Stanculescu, I.R., Hybrid materials based on $\mathrm{ZnO}$ and SiO2 nanoparticles as hydrophobic coatings for textiles, In: Industria Textila, 2020, 71, 297-301, http://doi.org/10.35530/IT.071.04.1814

\section{Authors:}

\section{SHEN LEI*, ZHANG XIYING*, REN XIANGFANG, CHEN HAN}

Jiangnan University, School of Design, Jiangnan University, 214122, Wuxi, China e-mail: 694341152@qq.com,942372345@qq.com,71952573@qq.com,7180306012@stu.jiangnan.edu.cn

*Authors contributed equally to this work

Corresponding author:

ZHANG XIYING

e-mail: 250915195@qq.com 